\title{
PCR-RFLP analysis of cpDNA in Gigantochloa scortechinii (Poaceae: Bambuseae) in Peninsular Malaysia and implications for the use of cpDNA markers in systematic studies
}

\author{
By N. Dhanendiren ${ }^{1)}$, H.Y. ONG ${ }^{1)}$, G. $\mathrm{KHOO}^{1)}$, K. M. $\mathrm{WONG}^{2)}$ and W. L. GoH ${ }^{1), *}$
}

(Received $12^{\text {th }}$ December 2015)

\begin{abstract}
Gigantochloa is a paleotropical woody bamboo genus that has been widely cultivated in $\mathrm{SE}$ Asia because of its usefulness. Recent studies have shown that species of this genus enter into an introgression complex with other genera of the same subtribe Bambusinae. Within G. scortechinii, a common species indigenous to Malay Peninsula and common in Peninsular Malaysia, two distinct chloroplast DNA (cpDNA) lineages, the Gombak- and Langattype, were recovered. We report the development of a PCR-based restriction fragment length polymorphism (RFLP) marker for depicting the genetic differentiation in $G$. scortechinii based on cpDNA. We determined a cpDNA region and its corresponding restriction enzyme which can produce different RFLP profiles for the two cpDNA lineages. Our design was verified with empirical studies. The Gombaktype was the dominant cpDNA genotype for G. scortechinii in Peninsular Malaysia. Implications for the continued use of cpDNA markers in systematic studies are discussed.
\end{abstract}

Key words: chloroplast capture, cpDNA differentiation, Gigantochloa, population genetics, restriction digestion

\section{Introduction}

Gigantochloa, a Southeast Asian woody bamboo genus that comprises 25 species (WIDJAJA and DRANSFIELD, 1995), is an economically important bamboo genus because a number of its species develop large-diameter, long and straight culm portions, and variously thick- to medium-walled culms useful for a variety of purposes. Classification of Gigantochloa at the

1) Faculty of Science, Universiti Tunku Abdul Rahman (UTAR), Jalan Universiti, Bandar Baru Barat, 31900 Kampar, Perak, Malaysia.

2) Singapore Botanic Gardens, 1 Cluny Road, Singapore 259569, Republic of Singapore.

*) Corresponding author: W. L. GoH.

Tel: +605-4688888, Fax: +605-4661676

E-Mail: wlgoh@utar.edu.my species level has been problematic on some fronts. Some of these species are morphologically closely related (WIDJAJA, 1987; WIDJAJA and Lester, 1987) and HoltTum (1958) even suggested the existence of Gigantochloa hybrid swarms, formed as a result of introgressive hybridisation among some closely related species. MULLER (1996, 1998, 1999, 2003) advocated that the Gigantochloa taxa that exist only in cultivation, and which are not known in the wild, could be "ancient enduring clones" (AECs) selected from such hybrid swarms and brought to the Malay Peninsula and Java from the Lower Burmese region (now Myanmar), the possible centre of diversity of Gigantochloa (HolTTUM, 1958), during the ancient migration of people from mainland Asia into insular Southeast Asia.

Gigantochloa scortechinii is one of the most abundant Gigantochloa species indigenous to Peninsular Thailand and Peninsular Malaysia. It is easily identifiable in the field by its bright orange culm sheaths covered with appressed dark hairs with green leaf-like blades and copiously white-waxy young culms (WoNG, 1995). Recent studies suggested that this species includes two distinct chloroplast DNA (cpDNA) haplotypes that fall into different subclades (BDG1 and BDG2) in a phylogenetic analysis of its subtribe, although the nuclear DNA data supports the uniformity of its genetic attribute (GoH et al., 2011; GoH et al., 2013). Besides, G. scortechinii is also able to hybridize naturally with Dendrocalamus pendulus, a member of a closely related genus of the same subtribe (GoH et al., 2011). It is, therefore, of interest to further investigate the extent of the cpDNA differentiation in G. scortechinii that could give insights into the possible role of introgressive hybridization in its evolution.

For the present study, restriction fragment length polymorphism (RFLP)-PCR was employed as it is rapid and yet effective for 
large scale screening in detecting single nucleotide polymorphisms (SNPs). It is used mainly for discriminating among selected species or detection of a particular species. PCR-RFLP is still the method of choice as shown by several recent studies such as the discrimination of harmful algae species (XIAO et al., 2013), detection of fungal variants (JuDOvA et al., 2012; NASRI et al., 2015), characterization of genetic variation in wheat (ALVAREz et al., 2013) and rapid authentication of processed fish products (MuELler et al., 2015; PAPPALARDO and FERRITO, 2015).

\section{Materials and methods}

\section{Plant materials}

Specimens of the Gigantochloa scortechinii species were collected from the townships of Kuala Kubu Bharu (Selangor) and Serendah (Selangor), the Sungai Gabai Waterfall (Selangor) and Janda Baik village (Pahang) using the morphological descriptions by WONG (1995). The collected juvenile leaves were preserved in silica gel. A culm sheath or a photo was taken as the voucher for each individual clone. The GPS coordinates were recorded (Table 1).

\section{Total DNA extraction and PCR amplification}

Total genomic DNA was isolated from approximately $0.05 \mathrm{~g}$ of the young leaf using the CTAB protocol modified from DoYLE and DOYLE (1987), Fulton et al. (1995) and DeshmukH et al. (2007). For each individual, non-coding cpDNA intergenic spacer rps16-trnQ was amplified using the PCR primers developed by BPG (2006). The PCR reaction mixture contained approximately $50 \mathrm{ng}$ of total DNA, $1 \times$ GoTaq Green Master Mix (Promega), 0.5 $\mathrm{\mu M}$ of both forward and reverse primers. Amplification was achieved in a MyCycler thermal cycler (BioRad) programmed for a preliminary 2 min denaturation step at $95^{\circ} \mathrm{C}$, followed by 35 cycles of denaturation at $95^{\circ} \mathrm{C}$ for $15 \mathrm{sec}$, annealing at $55^{\circ} \mathrm{C}$ for $30 \mathrm{sec}$ and extension at $72^{\circ} \mathrm{C}$ for $1 \mathrm{~min}$ $30 \mathrm{sec}$, finally at $72^{\circ} \mathrm{C}$ for $2 \mathrm{~min}$.

\section{Restriction enzyme digestion}

The cpDNA rps16-trnQ of two individuals from Genbank (accession numbers HQ697864.1 and HQ697861.1, hereafter named as Gombak and Langat, respectively), representing subclades BDG1 and BDG2, were aligned in order to identify their SNPs. The NEB cutter 1.0 (VINCZE et al., 2003) was used to search for the restriction enzymes that cut at the SNPs. The expected band profiles using the selected restriction enzymes were screened for their usefulness in differentiating the two subclades.

The amplified rps16-trnQ fragment was digested using the ApoI restriction enzyme following the manufacturer's protocols. Digested products were separated alongside a molecular weight marker (100 bp GeneDireX ${ }^{\circledR}$ H3 RTU) by electrophoresis on $2 \%$ agarose gels run in $0.5 \times$ TAE buffer, stained with ethidium bromide and visualized under UV light. Gel photographs were scanned through GeneSnap (SynGene).

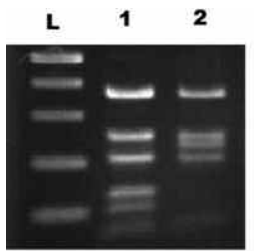

(a)

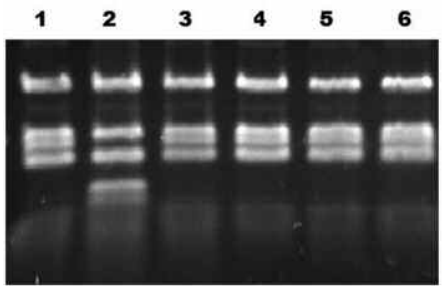

(d)

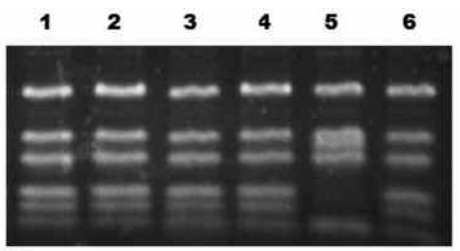

(b)

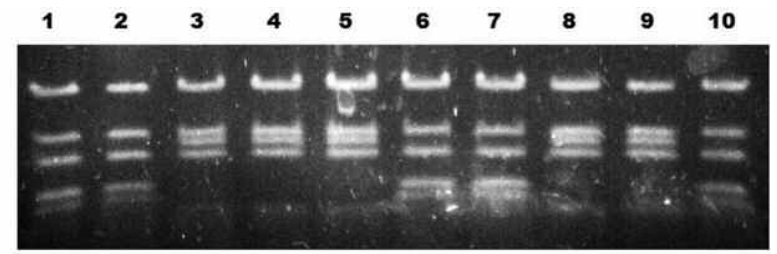

(c)

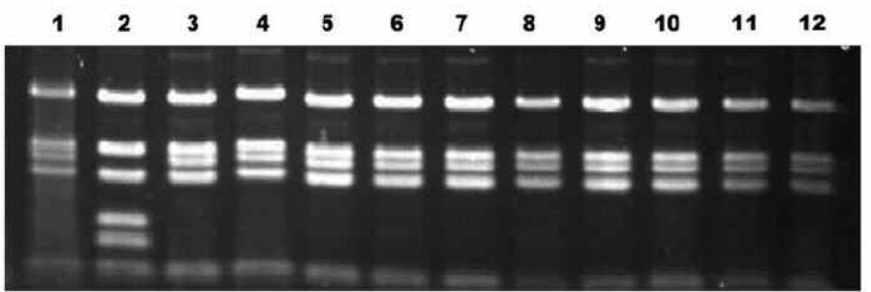

(e)

Figure 1. - PCR-RFLP profiles of (a) Langat (lane 1) and Gombak (lane 2), (b) DS4 - DS10 (lanes 1 - 6), (c) DS11 - DS20 (lanes 1 - 10), (d) DS21 - DS26(lanes 1 - 6), (e) DS29, DS32, DS33, DS34, DS36, DS38, DS39, DS40, DS41, DS42, DS43 and DS44 (lanes 1 - 12). Lane L indicates 100 bp DNA ladder (GeneDireX ${ }^{\circledR}$ H3 RTU). 


\section{DNA data analysis}

For verification purposes, the chloroplast rps16-trnQ and trnD-T (BPG 2006) regions of DS24, DS32 and DS36 were sequenced (First Base Laboratories Sdn. Bhd. Malaysia; Genbank accession numbers: KX235228 to KX235233). DNA data were aligned with the published sequences of three other G. scortechinii specimens, namely Gombak, Langat and Acc.52, (HQ697864, HQ697861, HQ697862, HQ697886, HQ697883 and HQ697884; GoH et al., 2011), the last from the living collection in Rimba Ilmu Botanic Gardens, University of Malaya and which was found to be of the Langat-type (GoH et al., 2011).

UPGMA phylogram was reconstructed using PAUP4.0 (Swofford 4.0) with Kinabaluchloa nebulosa (FJ416360 and GU390959) and Holt- tumochloa magica (FJ416348 and GU390958) as the outgroups.

\section{Results}

\section{RFLP marker selection}

The screening of suitable restriction enzymes generated using the NEB cutter 1.0 shows that MlucI, ApoI, AgsI and MseI were able to distinguish the different cpDNA types of $G$. scortechinii (Figures 1(a) and Table 2). MlucI and $M s e I$ were, however, expected to produce too many bands that can cause confusion in band scoring.

Digestion using the ApoI restriction enzyme resulted in the banding profiles of $100 \mathrm{bp}, 128$ bp, $156 \mathrm{bp}, 261 \mathrm{bp}$, and $370 \mathrm{bp}$ for Langat, while

Table 1. - Gigantochloa scortechinii specimens collected for this study and their cpDNA types. The grey shaded specimens are Langat-type while the non-shaded ones are Gombak-type.

\begin{tabular}{|c|c|c|c|}
\hline $\begin{array}{l}\text { Populat } \\
\text { ion }\end{array}$ & Collection Locality (Date) & $\begin{array}{l}\text { Collection } \\
\text { Number }\end{array}$ & GPS Coordinates \\
\hline \multirow{11}{*}{1} & \multirow{11}{*}{$\begin{array}{l}\text { Road from Kuala Kubu } \\
\text { Bharu to Fraser Hill, } \\
\text { Selangor } \\
\text { (24 Dec 2014) }\end{array}$} & DS4 & N $03^{\circ} 34.101^{\prime} ;$ E $101^{\circ} 41.073^{\prime}$ \\
\hline & & DS5 & N $03^{\circ} 37.242^{\prime} ; \mathrm{E} 101^{\circ} 38.133^{\prime}$ \\
\hline & & DS6 & 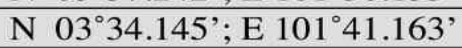 \\
\hline & & DS7 & N $03^{\circ} 34.148^{\prime} ;$ E $101^{\circ} 41.169^{\prime}$ \\
\hline & & DS8 & N $03^{\circ} 35.561^{\prime} ;$ E $101^{\circ} 44.098^{\prime}$ \\
\hline & & DS9 & N $03^{\circ} 35.579^{\prime} ; \mathrm{E} 101^{\circ} 44.126^{\prime}$ \\
\hline & & DS10 & N $03^{\circ} 36.047^{\prime} ;$ E $101^{\circ} 44.269^{\prime}$ \\
\hline & & DS11 & N $03^{\circ} 36.048^{\prime} ;$ E $101^{\circ} 44.263^{\prime}$ \\
\hline & & DS12 & N $03^{\circ} 36.399^{\prime} ;$ E $101^{\circ} 44.416^{\prime}$ \\
\hline & & DS13 & N $03^{\circ} 36.562^{\prime} ;$ E $101^{\circ} 44.446^{\prime}$ \\
\hline & & DS14 & N $03^{\circ} 36.560^{\prime} ;$ E $101^{\circ} 44.451^{\prime}$ \\
\hline \multirow{9}{*}{2} & \multirow{9}{*}{$\begin{array}{l}\text { Serendah, Selangor } \\
\quad(24 \text { Dec 2014) }\end{array}$} & DS15 & N $03^{\circ} 21.967^{\prime} ;$ E $101^{\circ} 37.710^{\prime}$ \\
\hline & & DS16 & N 0321.999'; E 101 $37.734^{\prime}$ \\
\hline & & DS17 & 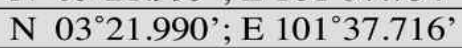 \\
\hline & & DS18 & N $03^{\circ} 21.971^{\prime} ;$ E $101^{\circ} 37.715^{\prime}$ \\
\hline & & DS19 & N $03^{\circ} 21.871^{\prime} ; \mathrm{E} 101^{\circ} 37.671^{\prime}$ \\
\hline & & DS20 & N $03^{\circ} 21.771^{\prime} ; \mathrm{E} 101^{\circ} 37.615^{\prime}$ \\
\hline & & DS21 & N $03^{\circ} 22.177^{\prime} ;$ E $101^{\circ} 37.862^{\prime}$ \\
\hline & & DS22 & N $03^{\circ} 22.178^{\prime} ;$ E $101^{\circ} 37.853^{\prime}$ \\
\hline & & DS23 & N 0321.994'; E 101 $36.743^{\prime}$ \\
\hline \multirow{6}{*}{3} & \multirow{6}{*}{$\begin{array}{l}\text { Sungai Gabai Waterfall, } \\
\text { Selangor } \\
(1 \text { Jan 2015) }\end{array}$} & DS24 & $\mathrm{N} 03^{\circ} 10.003^{\prime} ; \mathrm{E} 101^{\circ} 54.581^{\prime}$ \\
\hline & & DS25 & N 0309.996'; E $101^{\circ} 54.570^{\prime}$ \\
\hline & & DS26 & N $03^{\circ} 10.000^{\prime} ; \mathrm{E} 101^{\circ} 54.543^{\prime}$ \\
\hline & & DS29 & N 0309.982'; E 10154.509' \\
\hline & & DS32 & N $03^{\circ} 10.186^{\prime} ;$ E $101^{\circ} 52.417^{\prime}$ \\
\hline & & DS33 & N $03^{\circ} 18.307^{\prime} ; \mathrm{E} 101^{\circ} 44.302^{\prime}$ \\
\hline \multirow{9}{*}{4} & \multirow{9}{*}{$\begin{array}{c}\text { Janda Baik, Pahang } \\
\text { (2 Jan 2015) }\end{array}$} & DS34 & N $03^{\circ} 19.873^{\prime} ;$ E $101^{\circ} 45.604^{\prime}$ \\
\hline & & DS36 & N 03⒛512'; E 10149.369' \\
\hline & & DS38 & N $03^{\circ} 20.411^{\prime} ; \mathrm{E} 101^{\circ} 49.461^{\prime}$ \\
\hline & & DS39 & N $03^{\circ} 20.346^{\prime} ; \mathrm{E} 101^{\circ} 49.535^{\prime}$ \\
\hline & & DS40 & N $03^{\circ} 20.132^{\prime} ;$ E $101^{\circ} 49.692^{\prime}$ \\
\hline & & DS41 & N $03^{\circ} 20.116^{\prime} ;$ E $101^{\circ} 49.697^{\prime}$ \\
\hline & & DS42 & N $03^{\circ} 20.209^{\prime} ;$ E $101^{\circ} 49.648^{\prime}$ \\
\hline & & DS43 & N $03^{\circ} 20.176^{\prime} ;$ E $101^{\circ} 49.639^{\prime}$ \\
\hline & & DS44 & N $03^{\circ} 20.206^{\prime} ; \mathrm{E} 101^{\circ} 49.645^{\prime}$ \\
\hline
\end{tabular}


Table 2. - Summary of the restriction enzymes and their respective cut sites that produce different RFLP profiles for Langat and Gombak.

\begin{tabular}{|c|c|c|c|c|}
\hline \multirow{2}{*}{$\begin{array}{l}\text { Restriction } \\
\text { enzyme }\end{array}$} & \multicolumn{2}{|c|}{ Langat } & \multicolumn{2}{|c|}{ Gombak } \\
\hline & $\begin{array}{l}\text { Number of cut } \\
\text { sites }\end{array}$ & $\begin{array}{l}\text { Expected } \\
\text { band sizes, bp }\end{array}$ & $\begin{array}{l}\text { Number of cut } \\
\text { sites }\end{array}$ & $\begin{array}{l}\text { Expected } \\
\text { band sizes, bp }\end{array}$ \\
\hline MlucI & 17 & $\begin{array}{l}4,5,8,14,25, \\
27,36,41,62, \\
63,67,76,78, \\
89,90,100, \\
225\end{array}$ & 18 & $\begin{array}{l}4,5,6,9,15, \\
25,26,36,44, \\
62,63,67,76, \\
78,89,90,99, \\
225\end{array}$ \\
\hline ApoI & 4 & $\begin{array}{l}100,127,156, \\
261,370\end{array}$ & 4 & $\begin{array}{l}9,156,233 \\
253,370\end{array}$ \\
\hline AgsI & 4 & $\begin{array}{l}100,130,161, \\
206,417\end{array}$ & 5 & $\begin{array}{l}100,104,108 \\
133,162,417\end{array}$ \\
\hline MseI & 10 & $\begin{array}{l}4,5,7,31,54, \\
63,123,134, \\
152,179,262\end{array}$ & 9 & $\begin{array}{l}5,7,31,61,63, \\
126,134,152, \\
180,262\end{array}$ \\
\hline
\end{tabular}

Table 3. - Variable sites (which are also parsimony-informative) and the indels extracted from the rps16-trnQ and the $\operatorname{trn} D$-T data matrices. Dash indicates gap. The individuals of Gombak-type are boldfaced.

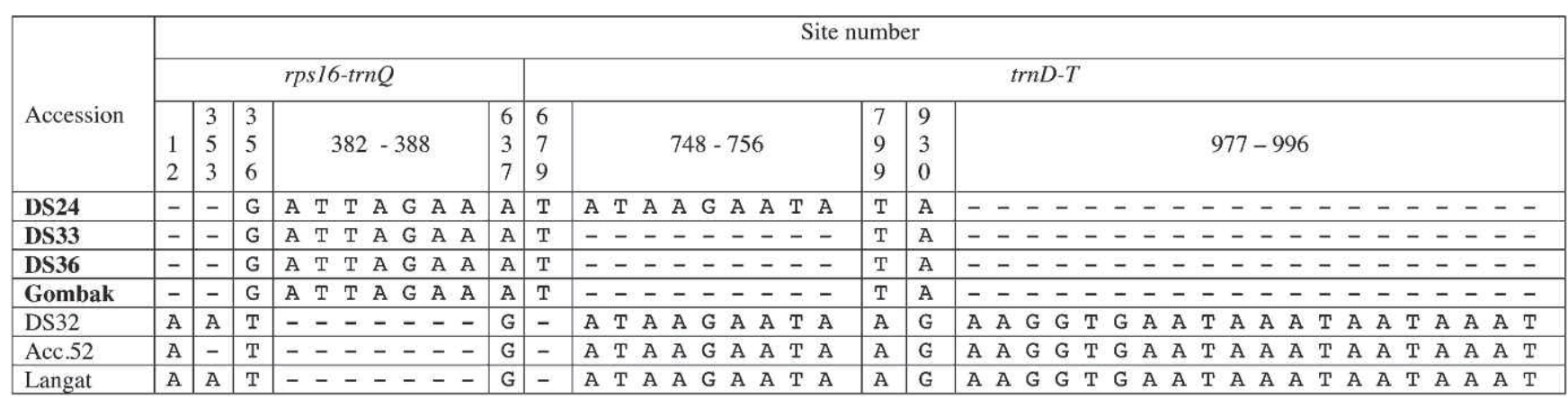

9 bp, 149 bp, 229 bp, 253 bp and 370 bp were observed for Gombak. These banding patterns were used to represent the two cpDNA genotypes of G. scortechinii.

\section{RFLP profiling using ApoI based on the chloroplast rps16-trnQ region}

The amplification of the chloroplast rps16$\operatorname{trn} Q$ region yielded a distinct band size of about $1.2 \mathrm{~kb}$. The ApoI digestion of the chloroplast rps16-trnQ region using the Langat and Gombak specimens resulted in two banding patterns. The Langat-type showed two bands between 200-300 bp, and two bands between 100-200 bp. The Gombak-type produced three bands between 200-300 bp, and none between 100-200 bp (Figure 1). The band sizes observed were slightly different from those estimated using the NEB cutter 1.0 because the virtual restriction digestion was performed using trimmed DNA sequence data.
Eight out of 11 individuals $(72.7 \%)$ from Kuala Kubu Baru, and four out of nine individuals $(44.4 \%)$ from Serendah were found to be of the Langat-type. Among the six individuals collected from Sungai Gabai Waterfall area (within the district of Hulu Langat in Selangor), only DS32 exhibits the Langat-type banding pattern. All individuals collected from Janda Baik village are of the Gombak-type (Table 1; Figure 1). All the bands were distinct and unambiguous.

\section{SNPs and indels}

The aligned data matrices of rps16-trnQ and trnD-T consist of 999 and 1101 characters, respectively. Variable sites $12,356,637,799$ and 930, as well as the 7 bp-indels (382-388) and the 20-bp indels (977-996) showed the distinctiveness between the Langat- and Gombaktypes (Table 3). It is, however, observed that the 9 bp-insertion (at sites 748-756) in DS24 resembled that in the Langat-type individuals 


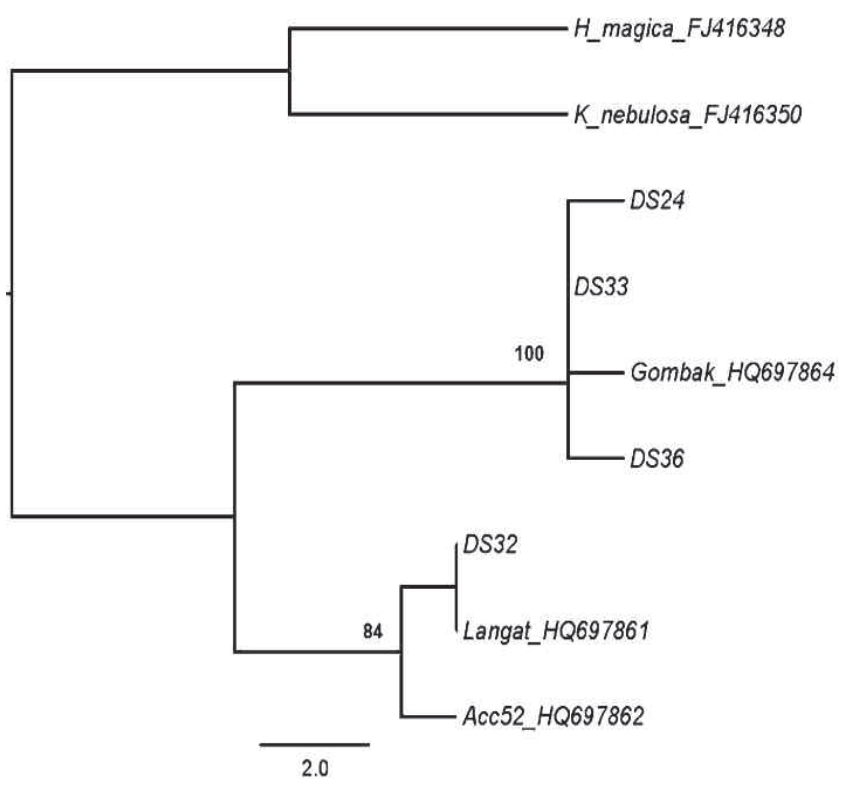

Figure 2. - UPGMA phylogram reconstructed for DS24, DS32, DS33, DS36, Acc.5, Gombak and Langat based on the combined rps16-trnQ + trnD-T region. Kinabaluchloa nebulosa and Holttumochloa magica were used as the outgroups.

(Table 3). The uniqueness of the Langat- and Gombak-types was also supported by the DNA data of the trnD-T region and the UPGMA dendrogram reconstructed based on the combined DNA data (Figure 2).

\section{Discussion}

\section{Chloroplast DNA differentiation in \\ G. scortechinii}

The two chloroplast genotypes in $G$. scortechinii were first noticed in phylogenetic studies by GoH et al. (2011) and GoH et al. (2013). The possibility of misidentification could be ruled out as G. scortechinii has conspicuous and consistent field characteristics, i.e., bright orange culm sheaths covered with dark appressed hairs on the adaxial surface and copious whitewaxy young culm internodes (WONG, 1995).

The existence of two distinct cpDNA haplotypes of G. scortechinii in Peninsular Malaysia is an indication of chloroplast capture $(\mathrm{GOH}$ et al., 2011), possibly resulted from possible backcrosses to the pollen parents after hybridization, i.e., introgression (RIESEBERG and Soltis, 1991), although the possibility of incomplete lineage sorting cannot be ruled out. This is not uncommon in various plant groups, namely Gossypium (Wendel and Albert, 1992), Sax- ifragaceae (Soltis et al., 1991; OKUYAMA et al., 2005), Pinaceae (WATANo et al., 1996; SENJo et al., 1999; Iто et al., 2008), Phlox (FERGUSON et al., 2002), Salix (HARDIG et al., 2000) and Nothofagus (Acosta and PREMoli, 2010), Osmorhiza (YI et al., 2015), as well as the North American bamboos, Arundinaria tecta and A. appalachiana (TRIPLETT et al., 2010). In this study, the donor of the foreign cpDNA is uncertain as each of the distinct cpDNA haplotypes was clustered with a few other genera and species (GoH et al., 2013), an observation attributed to a widespread introgression among the members of the Bambusa-DendrocalamusGigantochloa (BDG) complex in the past.

Interspecific fertilization often occurs when the seed parent is present in minority, allowing out competition of same-species pollen by pollen of another species (RIESEBERG, 1995); it is also expected that individuals that carry the foreign chloroplast will be low in frequency. Of the three populations with both Gombak- and Langat-type cpDNA, the Serendah and Sungai Gabai Waterfall populations had higher frequencies of Gombak-type compared to those of the Langat-type. Overall, among the 33 individuals sampled across four localities in Peninsular Malaysia, the Gombak-type is more abundant than the Langat-type $(60.7 \%$ vs. $39.3 \%$ ), suggesting that the former is the dominant cpDNA genotype for $G$. scortechinii. It is not impossible, however, that the ratio could change when sampling is extended.

Among the four sampling sites, Kuala Kubu Bharu and Serendah recorded relatively higher precentage of the Langat-type. Specimens from both Kuala Kubu Bharu and Serendah were from relatively more disturbed places compared to the sampling sites in Sungai Gabai Waterfall area and Janda Baik. In Kuala Kubu Bharu, specimens were collected along the roadside where a dam is located. In Serendah, samples were collected from an aboriginal settlement and suburb. This implies that anthropogenic environmental changes could have promoted cpDNA introgression in $G$. scortechinii.

\section{Implications for systematic studies}

Our observations conform to the past introgression suggested for the BDG complex $(\mathrm{GoH}$ et al., 2013). We suggest that inconsistencies among cpDNA-based phylogenies in previous studies of Southeast Asian woody bamboos 
(YANG et al. 2008; SungKAEW et al. 2009; YANG et al., 2010; GoH et al., 2013) could be partially due to such chloroplast capture. As shown by the results for Kuala Kubu Baru, the introgressed individuals could be predominant in certain localities. These results have implications for the sampling of taxa for molecular systematic studies of woody bamboos. It may be that sampling should at least follow the predominant morphological form of a taxon, or be carried out within the predominant center of distribution of such a typical form, and in cases possibly be guided by a quick preliminary profiling by methods such as we have employed.

\section{Conclusions and future work}

While conventional DNA profiling methods have lost some popularity along with advances in molecular techniques, here we demonstrate the use of PCR-RFLP for a rapid screening of two chloroplast genotypes in G. scortechinii. Use of PCR-RFLP is still a cost-effective and rapid preliminary screening method for population genetic screening or low-level systematic studies that usually involve a large number of specimens.

Notwithstanding, it is apparent that the captured variation has interesting connotations (e.g., as to which is the dominant or basic genotype) influenced by geographic scale and the scope of sampling. Our results make it interesting for additional studies to be made that would involve a wider sampling in Peninsular Malaysia, especially in relation to the fringes of G. scortechinii distribution and how chloroplast capture may involve other species of adjacent or sympatric distribution.

These results also imply that analyses with nuclear DNA might be expected to better reflect the larger distinctive phylogenetic traits and therefore be an important basis in understanding the systematic of the woody bamboos. Some studies based on nuclear markers have already begun to yield such systematic information and a more intensive use of nuclear markers seems prospective.

\section{Acknowledgments}

This study was supported by the UTAR Research Fund 2014-C1/G02. N. Dhanendiren received the MyBrain15 scholarship. K.M. WonG's participation was made possible by the National Parks Board, Singapore. The authors thank S.T. ANG, W.K. KHoO, K.S. Koo and N. ZAINUDDIN for their assistance in sample collection and preparation. We thank the anonymous reviewer for his valuable comments.

\section{References}

Acosta, M. C. and A. C. Premolin (2010): Evidence of chloroplast capture in South American Nothofagus (subgenus Nothofagus, Nothofagaceae). Molecular Phylogenetics and Evolution 54: 235-242.

Alvarez, J. B., S. Carmona and L. Caballero (2013): Identification and characterization by PCR-RFLP analysis of the genetic variation for the Glu-A1x and Glu-B1x genes in rivet wheat (Triticum turgidum L. ssp. turgidum). Journal of Cereal Science 57: 253-257.

Bamboo Phylogeny Group (2005): L.G. Clark Lab: sequencing primers and PCR protocols. http://www.eeob.iastate.edu/research/bamboo/pdf/ PCR_protocols.pdf.

Dransfield, S. and E. A. WidJAJA (1995): Plant Resources of South-East Asia No. 7: Bamboos. Backhuys Publishers, Leiden.

FERGuson, C. J. and R. K. JANSEN (2002): A chloroplast DNA phylogeny of eastern Phlox (Polemoniaceae): implications of congruence and incongruence with the ITS phylogeny. American Journal of Botany 89: 1324-1335.

Goh, W. L., S. Chandran, R. S. Lin, N. H. Xia and K. M. Wong (2010): Phylogenetic relationships among Southeast Asian climbing bamboos (Poaceae: Bambusoideae) and the Bambusa complex. Biochemical Systematics and Ecology 38: 764-773.

Goh, W. L., S. Chandran, D. C. Franklin, Y. Isagi, K. C. Koshy, S. Sungkaew, H. Q. Yang, N. H. XIA and K. M. Wong (2013): Multi-gene region phylogenetic analyses suggest reticulate evolution and a clade of Australian origin among paleotropical woody bamboos (Poaceae: Bambusoideae: Bambuseae). Plant Systematics and Evolution 299: 239-257.

GoH, W. L., S. Chandran, K. KamiYa and K. M. Wong (2011): A natural hybrid between Dendroalamus pendulus and Gigantochloa scortechinii (Poaceae: Bambusoideae) in Peninsular Malaysia. Gardens' Bulletin Singapore 62: 223-238.

Hardig, T. M., S. J. Brunsfeld, R. S. Fritz, M. MorGAN and C. M. ORIANS (2000): Morphological and molecular evidence for hybridization and introgression in a willow (Salix) hybrid zone. Molecular Ecology 9: 9-24.

Ito, M., Y. Suyama, T. A. Ohsawa and Y. Watano (2008): Airborne-pollen pool and mating pattern in a hybrid zone between Pinus pumila and P. parvi- 
flora var. pentaphylla. Molecular Ecology 17: 5092-5103.

Judova, J., K. Dubikova, S. Gaperova, J. Gaper and P. PRISTAS (2012): The occurrence and rapid discrimination of Fomes fomentarius genotypes by ITS-RFLP analysis. Fungal Biology 116: 155-160.

Mueller, S., S. M. Handy, J. R. Deeds, G. O. George, W. J. Broadhead, S. E. Pugh and S. D. GARRETT (2015): Development of a COX1 based PCR-RFLP method for fish species identification. Food Control 55: 39-42.

Muller, L. (1996): Cultivated Gigantochloa: escape from "death by flowering". ABS Newsletter 17: 4-7.

MulleR, L. (1998): Flowering and fruiting of a Gigantochloa ridleyi clone, seed germination and growth. ABS Newsletter 19: 8-11.

MULLER, L. (1999): The many reproductive modes of clumping bamboos. American Bamboo Soc. Newsletter 20(5): 1-4.

Muller, L. (2003): Gigantochloa ridleyi hybrids and affiliated bamboos. Bamboo bulletin 5: 16-19.

Nasri, T., M. T. Hedayati, M. Abastabar, A. C. Pasqualotto, M. T. Armaki, A. Hoseinnejad and M. NABILI (2015): PCR-RFLP on $\beta$-tubulin gene for rapid identification of the most clinically important species of Aspergillus. Journal of Microbiological Methods 117: 144-147.

OKuYAMA, Y., N. FuJi, M. WAKabaYAShI, A. Kawakita, M. Ito, M. Watanabe, N. Murakami and M. Kato (2005): Non-uniform concerted evolution and chloroplast capture: heterogeneity of observed introgression patterns in three molecular data partition phylogenies of Asian Mitella (Saxifragaceae). Molecular Ecology 22: 285-296.

Pappalardo, A. M. and F. Venera (2105): A COIBarRFLP strategy for the rapid detection of Engraulis encrasicolus in processed anchovy products. Food Control 57: 385-392.

RIESEBERG, L. H. (1995): The role of hybridization in evolution: old wine in new skins. American Journal of Botany 82: 944-953.

RieseberG, L. H. and D. E. Soltis (1991): Phylogenetic consequences of cytoplasmic gene flow in plants. Evolutionary Trends in Plants 5: 65-84.

SEnJo, M., K. Kimura and Y. Watano (1996): Extensive mitochondrial introgression from Pinus pumila to $P$. parviflora var. pentaphylla (Pinaceae). Journal of Plant Research 112: 97-105.

Soltis, D. E., P. S. Soltis, T. G. Collier and M. L. EDGERTON (1991): Chloroplast DNA variation within and among genera of the Heuchera group (Saxifragaceae): evidence for chloroplast transfer and paraphyly. American Journal of Botany 78: 1091-1112.
Swofford, D. L. (2002): PAUP*. Phylogenetic Analysis Using Parsimony ("and Other Methods), Version 4. Sinauer Associates, Sunderland, Massachusetts.

Sungkaew, S., C. M. A. Stapleton, N. Salamin, T. R. Hodkinson (2009): Non-monophyly of the woody bamboos (Bambuseae; Poaceae): a multi-gene region phylogenetic analysis of Bambusoideae s.s. Journal of Plant Research 122: 95-108.

Triplett, J. K., K. A. Oltrogge and L. G. Clark (2010): Phylogenetic relationships and natural hybridization among the North American woody bamboos (Poaceae: Bambusoideae: Arundinaria). American Journal of Botany 97: 1-22.

Vincze, T., J. Posfai and R. J. RoBerts (2003): NEB cutter: a program to cleave DNA with restriction enzymes. Nucleic Acids Research 31: 3688-3691.

Watano, Y., M. ImazU and T. ShImizu (1996): Spatial distribution of cpDNA and mtDNA haplotypes in a hybrid zone between Pinus pumila and P. parviflora var. pentaphylla (Pinaceae). Journal of Plant Research 109: 403-408.

WidjaJA, E. A. and S. Dransfield (1995): Plant Resources of Southeast Asia No.7. Bamboos. Backhuys Publishers, Leiden.

Wong, K. M. (1995): The Bamboos of Peninsular Malaysia. Forest Research Institute Malaysia, Sabah: 200.

YANG, H. Q., J. B. YANG, Z. H. PenG, J. GAO, Y. M. YANG, S. Peng and D. Z. Li (2008): A molecular phylogenetic and fruit evolutionary analysis of the major groups of the paleotropical woody bamboos (Gramineae: Bambusoideae) based on nuclear ITS, GBSSI gene and plastid trnL-F DNA sequences. Molecular Phylogenetic Evolution 48: 809-824.

XiaO, J., Y. Li, W. Song, Z. Wanga, M. Fu, R. Li, X. ZHANG and M. ZHU (2013): Discrimination of the common macroalgae (Ulva and Blidingia) in coastal waters of Yellow Sea, northern China, based on restriction fragment-length polymorphism (RFLP) analysis. Harmful Algae 27: 130137.

YANG, J. B., H. Q. YANG, D. Z. LI, K. M. Wong and Y. M. YANG (2010): Phylogeny of Bambusa and its allies (Poaceae: Bambusoideae) inferred from nuclear GBSSI gene and plastid psbA-trnH, rpl32trnL and rps16 intron DNA sequences. Taxon 59, 1102-1110.

YI, T., G. JIN and J. WEN (2015): Chloroplast capture and intra- and inter-continental biogeographic diversification in the Asian - New World disjunction plant genus Osmorhiza (Apiceae). Molecular Phylogenetics and Evolution 85: 10-21.

Herausgeber: Johann Heinrich von Thünen-Institut. Bundesforschungsinstitut für Ländliche Räume, Wald und Fischerei. Schriftleitung: Institut für Forstgenetik, Sieker Landstrasse 2, D-22927 Grosshansdorf Verlag: J. D. Sauerländer's Verlag, Berliner Strasse 46, D-63619 Bad Orb Anzeigenverwaltung: J. D. Sauerländer's Verlag, Bad Orb

Gesamtherstellung: PPPP Norbert Wege e.K., Gladenbach — Printed in Germany. 